\title{
Effect of Secretin on Basal- and Glucose-Stimulated Insulin Secretion in Man
}

\author{
J. Fahrenkrug, O. B. Schaffalitzky de Muckadell, and C. Kühl \\ Departments of Clinical Chemistry and Internal Medicine (T), Bispebjerg Hospital, Copenhagen, Denmark
}

\begin{abstract}
Summary. Plasma immunoreactive secretin and insulin concentrations were measured in fasting normal humans after intraduodenal infusions of hydrochloric acid, isotonic or hypertonic glucose. The effect of intraduodenal acidification or intravenous bolus injections of secretin on plasma insulin concentrations during infusions of glucose was also examined. The intraduodenal glucose load did not cause an increase in plasma secretin concentrations. Secretin concentrations rose after acid both in the fasting state and during infusions of glucose. A concomitant rise in insulin levels was however only observed during infusions of glucose. Intravenous injection of secretin in a dose which mimicked the response to intraduodenal acidification was without effect on the glucose-stimulated insulin release, while a 30 times higher dose caused a highly significant augmentation of the insulin release. The insulin response pattern to this high dose of secretin differed completely from that observed after intraduodenal infusion of acid. It is concluded and confirmed that the stimulating effect of secretin on insulin secretion is pharmacological and that secretin plays no significant role in the entero-insular axis.
\end{abstract}

Key words: Blood glucose, entero-insular axis, hydrochloric acid, insulin, radioimmunoassay, secretin.

Intrajejunal administration of glucose results in a considerably greater rise in serum insulin concentrations than intravenous administration of glucose at the same rate [1]. This difference in insulin response has been attributed to the operation of an enteroinsular axis entailing enhanced release of insulin by gastrointestinal hormones [2]. Concerning the action of secretin on insulin secretion, stimulation [3-16] as well as no effect [17-21] have been reported.

Criteria by which the role of a substance in the entero-insular axis is established must include demonstration of a release of the substance by oral secretagogues which normally release insulin (notably glucose), and demonstration that intravenous administration of a pure preparation of the substance in doses mimicking its physiological release, will augment the insulin response to elevated blood glucose.

Having established a sensitive and reliable radioimmunoassay for secretin we decided to reinvestigate the effect of endogenous and exogenous secretin on basal- and glucose-stimulated insulin secretion in man. Taking advantage of the measurements of secretin we were able to clarify if secretin played any physiological role.

\section{Material and Methods}

\section{Subjects and Experimental Procedures}

Seven healthy normal weight subjects ( 3 male: 4 female) all members of the paramedical staff volunteered for the study after the nature, purpose and possible risks had been carefully explained to them. Ages ranged from 19 to 36 years (mean, 28 years). Subjects were on a diet containing at least $250 \mathrm{~g}$ carbohydrates per day for 3 days before each investigation. Each subject was examined on seven different occasions at intervals of not less than 5 days. The experiments were performed in randomized order after an overnight fast. Intraduodenal infusion of test substances was accomplished via a nasoduodenal polyethylene tube positioned under fluoroscopic control with the tube opening into the second part of the duodenum. The position of the tube was confirmed 

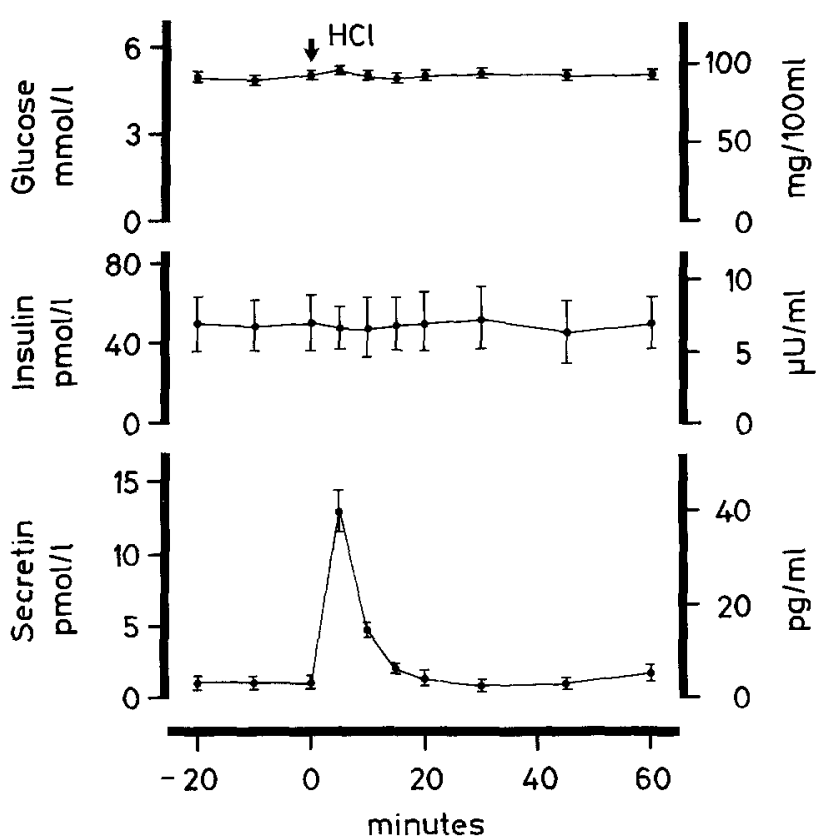

Fig. 1. Effect of intraduodenal infusion of $\mathrm{HCl}(40 \mathrm{ml}, 0,1 \mathrm{~mol} / \mathrm{l})$ on plasma secretin, plasma insulin and plasma glucose concentrations in seven normal fasting subjects. Values are given as means \pm SEM

after each experiment. Blood samples for secretin, insulin and glucose determinations were collected from a cannula inserted into an antecubital vein. Secretin injections and glucose infusions were given intravenously in the opposite arm. The blood samples were centrifuged at $4^{\circ} \mathrm{C}$ within $60 \mathrm{~min}$ after sampling. Immediately after centrifugation plasma was frozen and stored at $-20^{\circ} \mathrm{C}$ until assayed.

Intraduodenal Acidification in the Basal State. Forty $\mathrm{ml} \mathrm{HCl} 0.1 \mathrm{~mol} / 1$ (made isotonic with $\mathrm{NaCl}$ ) was infused into the duodenum of each subject over a period of $3 \mathrm{~min}$. Blood samples were withdrawn at 20,10 and $0 \mathrm{~min}$ before and 5, 10, 15, 20,30, 45 and $60 \mathrm{~min}$ after the onset of the infusion.

Intraduodenal Glucose Loading. Intraduodenal infusions of $40 \mathrm{ml}$ of isotonic glucose $(0.3 \mathrm{~mol} / \mathrm{l})$ or $40 \mathrm{ml}$ hypertonic glucose $(1.4 \mathrm{~mol} / \mathrm{l})$ were accomplished using the same protocol as for $\mathrm{HCl}$. The glucose solutions were adjusted to $\mathrm{pH} 7.0$ with $\mathrm{NaOH} 0.15 \mathrm{~mol} / \mathrm{l}$.

Intraduodenal Infusion of Saline. In these control experiments an identical volume of isotonic $\mathrm{NaCl}$ was infused instead of $\mathrm{HCl}$ and glucose.

Intraduodenal Acidification during Intravenous Infusion of Glucose. A stable plasma glucose concentration of approximately $11 \mathrm{mmol} / \mathrm{l}$ was rapidly reached by giving an intravenous priming dose of glucose,
$250 \mathrm{mg}(1.39 \mathrm{mmol}) / \mathrm{kg}$, in addition to a constant infusion of $10 \mathrm{mg}(0.56 \mathrm{mmol}) / \mathrm{kg}$. min (Dick pump, Copenhagen, Denmark). Thirty min after the start of the glucose infusion, endogenous secretin was released by intraduodenal infusion of $40 \mathrm{ml} \mathrm{HCl} 0.15$ $\mathrm{mol} / \mathrm{l}$. Blood samples were withdrawn at 20,10 and 0 min and $1,2,3,4,5,10,15,20,30,45$ and $60 \mathrm{~min}$ after the onset of the duodenal acidification.

Intravenous Injections of Secretin. Thirty min after the onset of the above mentioned intravenous glucose infusion, secretin (pure natural porcine secretin, GIH Research Laboratory, Karolinska Institutet, Stockholm, Sweden) was injected intravenously in the course of a few seconds. Two doses were used: 1 ) a small dose of $0.5 \mathrm{pmol} / \mathrm{kg}$ body weight, which mimicked the secretin response to intraduodenal acidification and 2) a large dose of $16 \mathrm{pmol} / \mathrm{kg}$. The calculated dose of secretin was dissolved in $5 \mathrm{ml}$ isotonic $\mathrm{NaCl}$. Blood samples were withdrawn at 20 , 10 and $0 \mathrm{~min}$ before and at $1,2,3,4,5,10,15$ and 20 min after the secretin injections.

\section{Laboratory Analysis}

Plasma secretin concentration was measured radioimmunochemically [22] using antibody 5595-3 raised to synthetic porcine secretin [23]. Synthetic secretin (kindly donated by Prof.E. Wünsch, MaxPlanck-Institut, Munich, GFR) was iodinated by a chloramine $\mathrm{T}$ method to a specific radioactivity of approximately $400 \mu \mathrm{Ci} / \mathrm{nmol}$ [24]. Pure natural porcine secretin (GIH Research Laboratory, Karolinska Institutet, Stockholm, Sweden) was used as standard and separation of free from antibody-bound labelled secretin was carried out using plasma-coated charcoal. The lowest concentration of secretin in plasma to be distinguished from zero with 95 per cent confidence was $1.3 \mathrm{pmol} / 1$. The within-assay coefficient of variation was 8.8 per cent and between-assay 9.7 per cent at a level of $22 \mathrm{pmol} / \mathrm{l}$. All samples were assayed in triplicate. Insulin concentration was measured by a sensitive radioimmunoassay utilizing Wick-chromatography as separation method [25]. The detection limit of the assay was less than $7 \mathrm{pmol} / 1(1 \mu \mathrm{U} /$ $\mathrm{ml}$ ) and between-assay coefficient of variation 10 per cent at a level of $144 \mathrm{pmol} / \mathrm{l}(20 \mu \mathrm{U} / \mathrm{ml})$. Plasma glucose was measured by a glucose-oxidase method on a Technicon Autoanalyzer [26].

\section{Statistical Analysis}

Statistical analysis was performed using the Wilcoxon matched-pairs signed-ranks test and the Friedman 


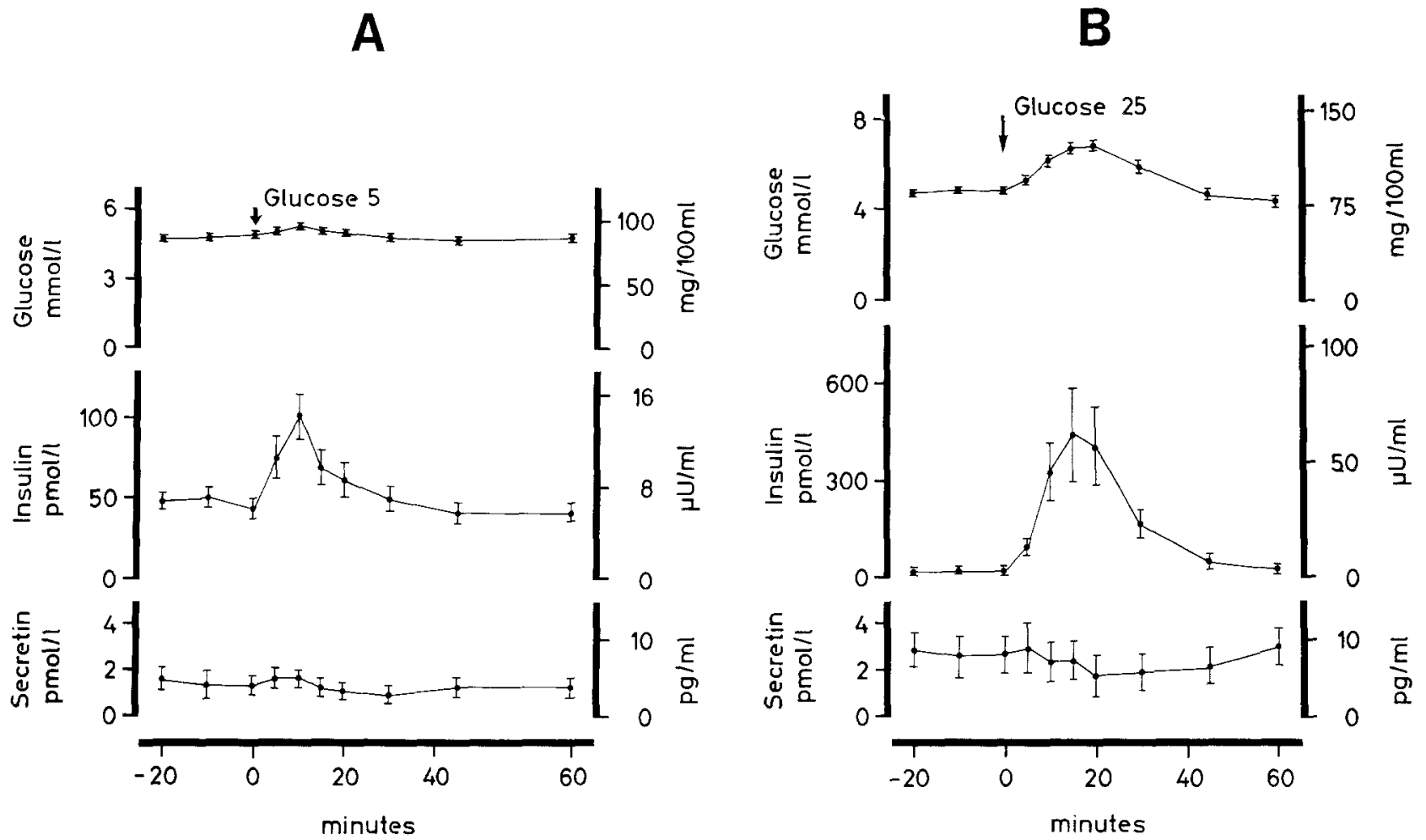

Fig. 2. Effect of intraduodenal infusion of A: $40 \mathrm{ml}$ isotonic glucose (glucose 5:5.5 per cent or $0.3 \mathrm{~mol} / \mathrm{l}$ ) and B: $40 \mathrm{ml}$ hypertonic glucose (glucose $25: 25$ per cent or $1.4 \mathrm{~mol} / \mathrm{l}$ ) on plasma secretin, plasma insulin and plasma glucose concentrations in seven normal fasting subjects. Values are given as means \pm SEM

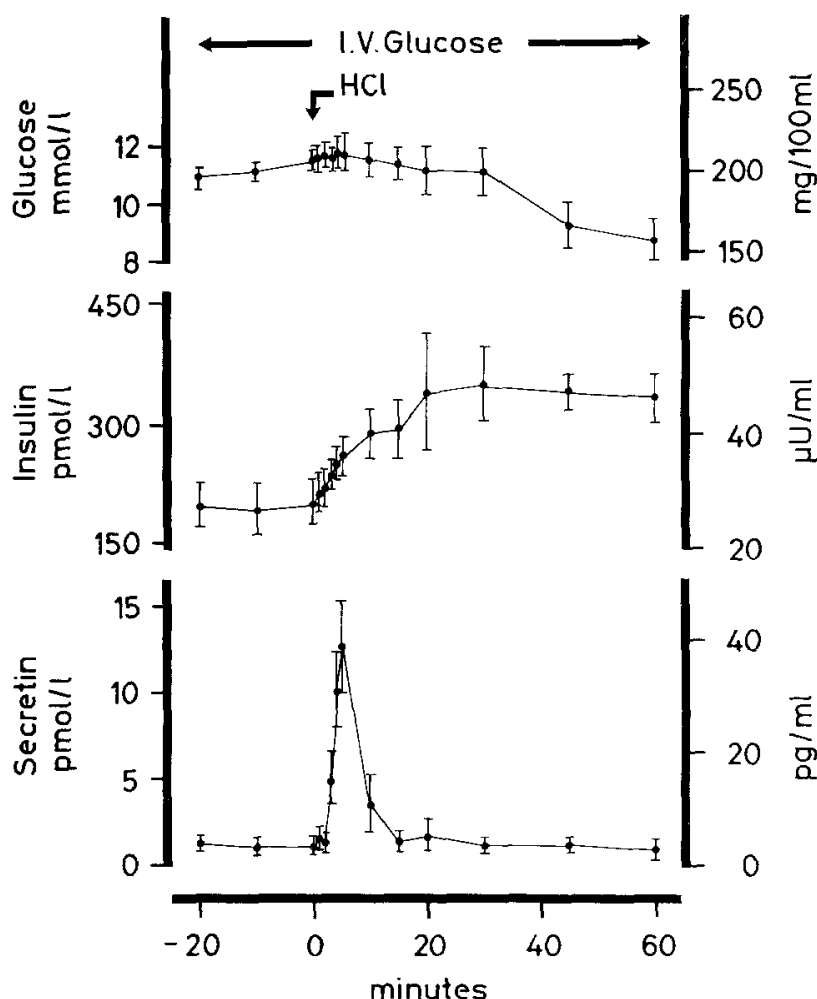

Fig. 3. Effect of intraduodenal infusion of $\mathrm{HCl}(40 \mathrm{ml}, 0.1 \mathrm{~mol} / \mathrm{l})$ on plasma secretin, plasma insulin and plasma glucose concentrations during intravenous infusion of glucose in seven normal subjects. Values are given as means \pm SEM two-way analysis of variance [27]. Differences resulting in $\mathrm{P}$ values of less than 0.05 were considered significant. Results are expressed as means \pm SEM.

\section{Results}

\section{Effect of Intraduodenal Acidification in the Basal State (Fig. 1)}

The infusion of $\mathrm{HCl}$ resulted in a significant rise in plasma secretin concentration from $1.3 \pm 0.4 \mathrm{pmol} / 1$ to a peak value of $13.0 \pm 1.2 \mathrm{pmol} / 1$ after $5 \mathrm{~min}$, which returned to the fasting level within $15 \mathrm{~min}$. Plasma insulin and plasma glucose concentrations were unaffected.

\section{Effect of Intraduodenal Glucose Loading (Fig. 2)}

After intraduodenal infusion of isotonic or hypertonic glucose no significant changes in plasma secretin concentration were observed. Ten min after the infusion of isotonic glucose the peak values in plasma glucose and plasma insulin concentrations were achieved, being $5.2 \pm 0.2 \mathrm{mmol} / 1$ and $101 \pm 14$ $\mathrm{pmol} / 1(14 \pm 2 \mu \mathrm{U} / \mathrm{ml})$, respectively. The corresponding values after hypertonic glucose were $6.8 \pm$ 

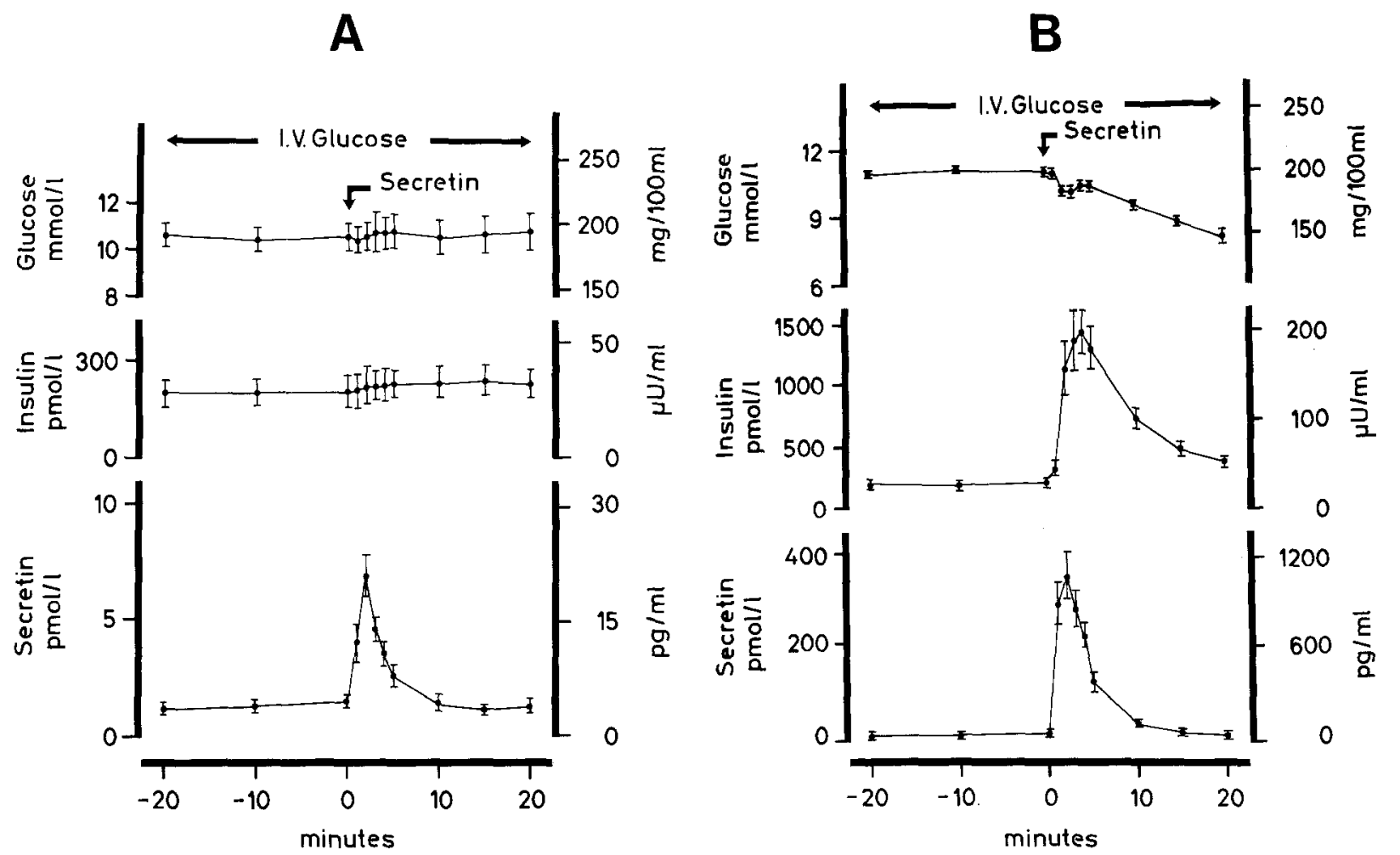

Fig. 4. Effect of bolus injections of secretin given intravenously in $\mathrm{A}$ : a physiological dose $(0.5 \mathrm{pmol} / \mathrm{kg})$ and $\mathrm{B}$ : in a pharmacological dose $(16 \mathrm{pmol} / \mathrm{kg})$ on plasma secretin, plasma insulin and plasma glucose concentrations during intravenous infusion of glucose in seven normal subjects. Values are given as means \pm SEM

$0.2 \mathrm{mmol} / \mathrm{l}$ and $450 \pm 148 \mathrm{pmol} / 1(63 \pm 21 \mu \mathrm{U} / \mathrm{ml})$ obtained after $20 \mathrm{~min}$ and $15 \mathrm{~min}$, respectively.

\section{Response to Intraduodenal Infusion of Saline}

No significant changes in plasma secretin, plasma insulin or plasma glucose concentrations were observed.

\section{Effect of Intraduodenal Acidification on Glucose- Stimulated Insulin Secretion (Fig. 3)}

Intravenous infusion of glucose resulted in plateau glucose and insulin concentrations averaging 11 $\mathrm{mmol} / 1$ and $200 \mathrm{pmol} / 1(28 \mu \mathrm{U} / \mathrm{ml})$, respectively. The infusion of $\mathrm{HCl}$ resulted in a significant increase in plasma secretin concentration from $1.4 \pm 0.5$ $\mathrm{pmol} / 1$ to a peak value of $12.8 \pm 2.8 \mathrm{pmol} / 1$ after 5 min. A return to basal levels was reached within 15 min. A significant increase in plasma insulin concentration was observed after $5 \mathrm{~min}$ and by $30 \mathrm{~min}$ after the intraduodenal acidification a maximum of $348 \pm$ $44 \mathrm{pmol} / \mathrm{l}(48 \pm 6 \mu \mathrm{U} / \mathrm{ml})$ was obtained. The concentration did not return to prestimulated value within the $60 \mathrm{~min}$ observation period. The rise in plasma insulin concentration was accompanied by a progressive and significant decrease in plasma glucose concentration.

\section{Effect of Exogenous Secretin on Glucose-Stimulated Insulin Secretion (Fig. 4)}

After bolus injection of secretin in a dose of 0.5 $\mathrm{pmol} / \mathrm{kg}$, plasma secretin concentration rose from 1.4 $\pm 0.3 \mathrm{pmol} / 1$ to a peak value of $6.8 \pm 0.9 \mathrm{pmol} / 1$ after $2 \mathrm{~min}$ and returned to the prestimulated level within $10 \mathrm{~min}$. No significant changes in plasma insulin or plasma glucose concentrations were observed. Injection of secretin in a dose of $16 \mathrm{pmol} / \mathrm{kg}$ resulted in a peak value in plasma secretin concentration of $352 \pm$ $52 \mathrm{pmol} / \mathrm{l}$ after $2 \mathrm{~min}$. This high dose of secretin was followed by a highly significant increase in plasma insulin concentration to a peak of $1417 \pm 199 \mathrm{pmol} / 1$ $(197 \pm 28 \mu \mathrm{U} / \mathrm{ml})$ after $4 \mathrm{~min}$ which returned to prestimulated values within $20 \mathrm{~min}$. In accordance with the insulin release a significant decrease in plasma glucose concentration to $8.2 \pm 0.7 \mathrm{mmol} / \mathrm{l}$ occurred.

\section{Discussion}

The present study has not provided evidence that secretin is a candidate in the entero-insular axis, since 
intraduodenal glucose loading did not cause the release of secretin and since exogenous secretin given intravenously in a dose which mimicked the secretin response to intraduodenal acidification was without effect on glucose-stimulated insulin secretion.

The lack of an increase in the plasma concentration of immunoreactive secretin after intraduodenal glucose administration is in accordance with results observed in anaesthetized dogs [28] and pigs [29]. As reported by O'Connor et al. [21] intraduodenal acidification was without effect on plasma insulin concentration in fasting man. During hyperglycaemia, however, the infusion of hydrochloric acid into the duodenum was associated with a long-lived augmentation of the insulin response (Fig. 3). This insulin response pattern differed completely from that observed after intravenous injection of a large dose of secretin (Fig. 4B) and thus other substances must be involved. Secretin is not the only gastrointestinal peptide which is released by intestinal acidification. Thus vasoactive intestinal polypeptide [30] and cholecystokinin [31] are both released. These peptides are both known to have an insulinogenic action [32] and might be responsible for the observed augmentation in the insulin response after intraduodenal infusion of hydrochloric acid. Gastric inhibitory polypeptide (GIP), which for the time being is considered to be the most important hormone in the entero-insular axis, is however not released by intestinal acidification (Lauritsen and Moody, personal communication).

During normal physiological conditions secretin is released in short-lived spikes resulting in concentrations in peripheral venous plasma which never exceed $10 \mathrm{pmol} / 1$ [33]. Thus, only the small dose of secretin used in the present study can be considered to be within the physiological range. This dose was without effect on plasma insulin and plasma glucose concentrations. The finding is consistent with the recent results of Enk [16], who in dose-response studies found that a secretin dose of $0.9 \mathrm{pmol} / \mathrm{kg}$ had no insulinogenic effect in normal subjects. The large dose of secretin used in this and in several previous studies was able to release biologically active insulin. This dose, however, results in plasma concentrations of secretin which are far above the upper limit of physiological range.

In conclusion, the stimulating effect of secretin on insulin secretion must be considered to be a pharmacological action and there is no evidence that secretin plays a significant role in the entero-insular axis under normal physiological conditions.

Acknowledgements. The skilful technical assistance of Anne Sylvest, Lene Poulsen, Nina Rasmussen and Hanne Dam is gratefully acknowledged. The study was supported by grants from The
NOVO Research Foundation, and The Danish Hospital Foundation for Medical Research, Region of Copenhagen, The Faroe Islands, and Greenland (j. nr. 74/75, 25, 75/76, 40, 76/77, 46).

\section{References}

1. McIntyre, N., Holdsworth, C. D., Turner, D. S.: New interpretation of oral glucose tolerance. Lancet 1964 II, 20-21

2. Perley, M.J., Kipnis, D.M.: Plasma insulin responses to oral and intravenous glucose: Studies in normal and diabetic subjects. J. Clin. Invest. 46, 1954-1962 (1967)

3. Dupré, J., Rojas, L., White, J.J., Unger, R.H., Beck, J.C.: Effects of secretin on insulin and glucagon in portal and peripheral blood in man. Lancet 1966 II, 26-27

4. Unger, R. H., Ketterer, H., Dupré, J., Eisentraut, A. M.: The effects of secretin, pancreozymin, and gastrin on insulin and glucagon secretion in anaesthetized dogs. J. Clin. Invest. 46, 630-645 (1967)

5. Deckert, T.: Stimulation of insulin secretion by glucagon and secretin. Acta Endocrinol. (Kbh.) 57, 578-584 (1968)

6. Dupré, J., Curtis, J.D., Unger, R. H., Waddell, R. W., Beck, J.C.: Effects of secretin, pancreozymin, or gastrin on the response of the endocrine pancreas to administration of glucose or arginine in man. J. Clin. Invest. 48, 745-757 (1969)

7. Chisholm, D. J., Young, J. D., Lazarus, L.: The gastrointestinal stimulus to insulin release 1 . Secretin. J. Clin. Invest. 48, 1453-1460 (1969)

8. Kaess, H., Schlierf, G., von Mikulicz-Radecki, J. G.: Effect of intraduodenal instillation of hydrochloric acid on plasma insulin levels of patients with portocaval shunts. Metabolism 19, 214-218 (1970)

9. Kraegen, E. W., Chisholm, D. J., Young, J. D., Lazarus, L.: The gastrointestinal stimulus to insulin release II. A dual action of secretin. J. Clin. Invest. 49, 524-529 (1970)

10. Lerner, R. L., Porte, D.: Uniphasic insulin responses to secretin stimulation in man. J. Clin. Invest. 49, 2276-2280 (1970)

11. Raptis, S., Schröder, K.E., Faulhaber, J.D., Pfeiffer, E.F.: Stimulation of insulin secretion by secretin in diabetics. Ger. Med. 15, 206-210 (1970)

12. Iversen, J.: Secretion of glucagon from the isolated perfused porcine pancreas. J. Clin. Invest. 50, 2123-2136 (1971)

13. Dudl, R., Lerner, R.L., Ensinck, J.W., Williams, R. H.: The effect of secretin on pancreatic glucoregulatory hormones in man. Horm. Metab. Res. 5, 250-253 (1972)

14. Shima, K., Tarui, S.: The effect of secretin on glucose-stimulated insulin secretion in man. Endocrinol. Jpn. 21, 13-18 (1974)

15. Coddling, J. A., Rappaport, A. M., Ashworth, A., Kalnins, A., Haist, R. E.: Effect on insulin output and pancreatic blood flow of glucagon, secretin, tolbutamide and thiocid infusions into an in situ isolated portion of pancreas. Horm. Metab. Res. 7, 199-204 (1975)

16. Enk, B.: Secretin induced insulin response. Acta Endocrinol. (Kbh.) 82, 312-317 (1976)

17. Boyns, D. R., Jarrett, R. J., Keen, H.: Intestinal hormones and plasma insulin: an insulinotropic action of secretin. Br. Med. J. 1967 II, 676-678

18. Mahler, R. J., Weisberg, H.: Failure of endogenous stimulation of secretin and pancreozymin release to influence serum insulin. Lancet 1968 I, 448-451

19. Kaess, H., Schlierf, G.: Veränderungen des Blutzuckers und der Plasmainsulinkonzentration nach stimulierung der endogenen sekretin freisetzung. Diabetologia 5, 220-232 (1969)

20. Schaffalitzky de Muckadell, O.B., Fahrenkrug, J., Kühl, C.: 
Plasma insulin concentration during physiological variations in immunoreactive plasma secretin. Horm. Metab. Res. 8, 253-256 (1976)

21. O'Connor, F. A., Buchanan, K.D., Connon, J. J., Shahidullah, M.: Secretin and insulin: Response to intraduodenal acid. Diabetologia 12, 145-148 (1976)

22. Schaffalitzky de Muckadell, O.B., Fahrenkrug, J.: Radioimmunoassay of secretin in plasma. Scand. J. Clin. Lab. Invest. 37, 155-162 (1977)

23. Fahrenkrug, J., Schaffalitzky de Muckadell, O.B., Rehfeld, J.F.: Production and evaluation of antibodies for radioimmunoassay of secretin. Scand. J. Clin. Lab. Invest. 36, 281-287 (1976)

24. Schaffalitzky de Muckadell, O. B., Fahrenkrug, J.; Preparation of ${ }^{125}$ I-labelled synthetic porcine secretin for radioimmunoassay. Scand. J. Clin. Lab. Invest. 36, 661-668 (1976)

25. Kühl, C.: Glucose metabolism during and after pregnancy in normal and gestational diabetic women. Acta Endocrinol. (Kbh.) 79, 709-719 (1975)

26. Trinder, P.: Determination of glucose in blood using glucose oxidase with an alternative oxygen acceptor. Ann. Clin. Biochem. 6, 24-27 (1969)

27. Siegel, S.: Non Parametric Statistics for the Behavioral Sciences, pp. 75-83, 166-172. New York: McGraw-Hill 1956

28. Boden, G., Essa, N., Owen, O.E., Reichle, F. A.: Effects of intraduodenal administration of $\mathrm{HCl}$ and glucose on circulating immunoreactive secretin and insulin concentrations. J. Clin. Invest. 53, 1185-1193 (1974)
29. Fahrenkrug, J., Schaffalitzky de Muckadell, O. B., Holst, J. J.: Plasma secretin concentration in anaesthetized pigs after intraduodenal glucose, fat, aminoacids, or meals with various pH. Scand. J. Gastroenterol. 12, 273-279 (1977)

30. Schaffalitzky de Muckadell, O. B., Fahrenkrug, J., Holst, J.J., Lauritsen, K. B.: Release of vasoactive intestinal polypeptide (VIP) by intraduodenal stimuli. Scand. J. Gastroenterol. 12, 793-799 (1977)

31. Reeder, D.D., Becker, H.D., Smith, N.J., Rayford, P.L., Thompson, J.C.: Measurement of endogenous release of cholecystokinin by radioimmunoassay, Ann. Surg. 178, 304-310 (1973)

32. Schebalin, M., Said, S. I., Makhlouf, M.: Stimulation of insulin and glucagon secretion by vasoactive intestinal peptide. Am. J. Physiol. 232, E 197-E 200 (1977)

33. Schaffalitzky de Muckadell, O.B., Fahrenkrug, J.: Secretin: Role in man. In: S. R. Bloom (ed.): Gut Hormones. Churchill Livingstone (in press) 1978

Received: August 16, 1977,

and in revised form: October 28, 1977

J. Fahrenkrug, M. D.

Department of Clinical Chemistry

Bispebjerg Hospital

Bispebjerg Bakke 23

DK-2400 Copenhagen NV

Denmark 